G

DOI: 10.1515/abcsj-2016-0002

\title{
Whither Teaching in the University Novel?
}

\author{
ELIZABETH K. SWITAJ
}

College of the Marshall Islands

\begin{abstract}
Scenes of explicit teaching make only limited appearances in the university novel since World War II. While it would be easy - if cynical to attribute this minimization to the devaluation of teaching in the modern university, the importance of teaching and learning to sympathetic characters (and their lack of importance to corrupted figures) suggests that this lack of focus on the classroom stems from something else. Indeed, university novels tend to be fairly conservative aesthetically, and the demands of traditional narrative make extended classroom scenes difficult if not impossible to manage. Because of these narrative demands, learning and teaching take on different forms in the university novel, creating stories in which education corresponds to the struggle of teachers and students with and against administrators and buildings - stories that, therefore, resemble Leo van Lier's observation about how remembering our own educations as stories contradicts more bureaucratic visions of learning. This observation holds true whether one considers better-known works of university fiction such as David Lodge's Campus Trilogy, Mary McCarthy's The Groves of Academe, and Julie Schumacher's Dear Committee Members or lesser-known works produced by micro-presses and writers who are enabled by current technologies to publish electronically.
\end{abstract}

Keywords: pedagogy, novel, narrative, memory, university fiction, David Lodge, Mary McCarthy, Julie Schumacher, Kingsley Amis, Daniel Curzon

The postwar Anglo-American university novel spends strikingly little time in the classroom, even when it is set entirely on campus. The Chronicle of Higher Education's pseudonymous columnist Ms. Mentor, for one, has 
complained of academic novels lacking "unpredictable classroom scenes." It would be easy - if cynical - to attribute this paucity to the relative unimportance of teaching and learning in the late twentieth and early twenty-first century university, relative to research and administrative responsibilities. Indeed, many of these novels parody the esoteric research interests of elite professors and lament administrative overreach on campus. It would be easy, similarly, to see the lack of classroom scenes as signs of increasingly anti-intellectual climates on some campuses, which many of these novels seek to critique. Nonetheless, such ascriptions oversimplify the case, overlooking both the nature of the novel and what campus novels demonstrate about the way education takes place beyond the classroom walls or the boundaries of the learning management system. In the same vein, it would be easy to attribute the lack of criticism questioning the minimization of classroom scenes in campus novels to a general lack of concern for teaching in academic life, but that would be to overlook the challenge of writing about what is absent from a novel rather than what is present.

The limited number of classroom scenes in university fiction, driven by the conventions of the novel, leads to the presence of a different way of considering learning and teaching. Leo Van Lier has stated that, reflected upon in hindsight,

[o]ur schooling becomes a remembered narrative, a narrated memory. This way of looking at education as a narrative or a story is a powerful counterweight to the prevailing view of schooling as an institution and a bureaucracy, enshrined in budgets and buildings, and defined by the collective struggles of administrators, teachers, students, and parents. (1)

University novels, whether told from the perspective of the educated or the educators, illustrate this principle. The demands of storytelling show how the role of the educator expands beyond the classroom and how it includes struggles precisely with those administrations and buildings that are so often falsely viewed as defining education - that is to say, the struggles of students and faculty against budgets, buildings, and administrative demands, rather than collective bureaucratized struggles are made into stories of learning both in fiction and in memory. In 
fulfilling the generic requirements of the traditional novel, university fiction creates alternative ways to understand learning and teaching.

Some campus novels do suggest a stronger focus on research than on teaching. In Theodore Weesner's Novemberfest (1994), for instance, when the protagonist who is seeking tenure complains that his teaching ought to count for his case, the dean responds that "You are a proven teacher; your evaluations are among the highest in the college ... But as you know, the guidelines state that at least one book is required for tenure" (10). More notorious is the case of David Lodge's Small World, yet it is his novels that in fact suggest that the focus on research need not be at the expense of teaching. In the Introduction to the 2011 Penguin edition of his Campus Trilogy, Lodge acknowledges that this novel has been criticized for showing academics spending lavish grants on travel to exotic locales to party and to present their work during a period when higher education funding was under threat - Thatcherite Britain in 1984. In truth, the carnivalesque atmosphere of the conferences suggests something other than pure research is at stake here, but whatever that may be, it is not shown necessarily to detract from teaching. Indeed, one of the characters, Morris Zapp, was already established as a well-regarded teacher in the trilogy's first novel, Changing Places (1975), not despite his research but because of it; a newsletter that seems to be Rate My Professor's ancestor, describes him as being, despite his personal failings, "brilliant and stimulating. 'He makes Austen sing"” (Lodge 54). Research, in other words, represents part of the act of educating. Moreover, even in the satiric Small World, "conference season" only opens in June after most teaching duties have been dispensed with:

In Oxford and Rummidge, to be sure, the students still sit at their desks in the examination halls, like prisoners in the stocks, but their teachers are able to flit off for a few days before the scripts come in for marking; in North America the second semester of the academic year is already finished, papers have been graded, credits awarded, and the faculty are free to collect their travel grants and head east, or west. (Lodge 427)

A stronger explanation for the limited depictions of classroom scenes has to do with the nature and generic requirements of these novels. In other words, we need to move beyond the popular perception, observed 
by Janice Rossen, that such novels contain "an accurate representation of academic life" (5) and consider them as constructed fictional narratives. With rare exceptions, novels do not attempt to represent everything that happens to a set of characters over a period of time. Even those that do seem to try to achieve such extreme realism, such as James Joyce's Ulysses, must at least select which details to share. What novelists do choose to depict generally serves to advance some combination of plot, character development, and/or theme. There are of course exceptions: the sermon that takes up most of the third chapter of Joyce's A Portrait of the Artist as a Young Man, for instance, would not need to be reproduced so extensively to serve these purposes, but in that case, it reflects an interest in how language and rhetoric change depending on age and context that most campus novels are too conservative to take up with the same degree of commitment.

The literary conservatism of the university novel has been welldocumented. In an article first published in 1964, Leslie Fiedler classed the college novel as a genre "born middlebrow" and while his judgment of such novels as being necessarily cliché (48) may be harsh, it is true that the postwar university novel has not, either in Fiedler's time or since, striven towards those experimental standards held up as highbrow since the advent of modernism. More recently, Terry Eagleton has described the novels of David Lodge, one of the most prominent producers of campus fiction, as "rarely [going] beyond the odd self-reflexive flourish or experimental narrative device within what remains a sedate, commercially acceptable realism" (97).

Rarely is most or all of the lecture required to meet one of the more standard criteria for inclusion in a novel. Hence, lectures in campus novels tend to be summarized or excerpted. In Lodge's Nice Work (1988), passages from Robyn Penrose's lecture on the Industrial Novels of the mid-nineteenth century appear interspersed with scenes of Vic Wilcox at work and Wilcox's wife and daughter in a café. The information presented in her lecture provides the non-specialist reader with the necessary background knowledge to see the parallels between Robyn's research and the situation in Wilcox's factory, while her pauses to take stock of her students help to establish her as a caring and concerned instructor. 
Because the action in other settings appears between these passages, however, the plot is not put on hold to provide this information (579-87). Similar uses of the classroom establish the themes of Daniel Curzon's Among the Carnivores (1978), a novel about the struggles of a gay man who begins teaching at Fresno State University in 1975. Six and a half pages are dedicated to a scene in which the protagonist, Jock, discusses avoiding stereotypes with his Advanced Creative Writing class; while not long enough to depict a class meeting in its entirety, the scene is longer than most uninterrupted scenes of pedagogy in campus novels, which works here because Curzon uses the scene to illuminate Jock's inner debate about how much of his life and his personal knowledge of the lives of gay men to reveal (62-68).

Seminars or small-group tutorials offer more opportunities than lectures to reveal character or advance a plot than lectures do because of their interactive nature and so tend to appear more often than full-fledged lectures. However, as long as they remain focused on a particular topic, there are constraints on these functions; like the lectures, they therefore tend to be excerpted or summarized. In the depiction of a tutorial that opens Malcolm Bradbury's Eating People Is Wrong (1960), the content and intellectual exchange are glossed over in favor of revealing details of Professor Treece's manner of speaking and feelings about his students, establishing his sense of belonging neither to the earlier generation of most of his peers nor the later generation of those he teaches. Later scenes contribute to the depiction of "[ $t]$ he problematics of the mainline liberal position" that, according to Keith Wilson, form the central theme of the novel (60). The only dialogue directly reported illustrates the difference between a returning-student member of the group, Louis Bates, and his peers. Changing Places similarly uses the tutorial to illustrate the character of its protagonists: Philip Swallow's letter about the minutiae of his tutorial groups students' personal lives illustrates the differences between his character and that of Zapp, the American professor with whom he exchanges positions, without actually showing any classroom activity (Lodge 49). Swallow demonstrates the care of a mother hen, much to Zapp's discomfiture. Later, Zapp's description of these same groups in a letter to his soon-to-be-ex wife serves to illustrate the 
differences between the UK and US higher education systems, as well as his own attitudes:

"I swear the system here will be the death of me. Did I say system? A slip of the tongue. There is no system here. They have something called tutorials, instead. Three students and me, for an hour at a time. We're supposed to discuss some text I've assigned. This, apparently, can be anything that comes into my head, except that the campus bookshop doesn't have anything that comes into my head." (Lodge 101)

As Zapp's sardonic description continues, he also reveals something about his pedagogy - albeit something fairly basic - a strong preference for student participation:

"When the guy reading the paper finally winds it up, I ask for comments. Silence. They avoid my eye. I volunteer a comment myself. Silence falls again. It's so quiet you can hear the guy's beard growing. Desperately I ask one of them direct question, 'And what did you think of the text, Miss Archer?' Miss Archer falls off her chair in a swoon.” (Lodge 101)

Rather than a direct representation of the classroom, Lodge gives the reader a highly compressed and, in places, hyperbolic representation that serves more to highlight Zapp's attitude and tone than to represent teaching; we never hear the paper; the agonizing silence of a class hesitant to speak is replaced with the humorous idea that a beard can make a sound as it grows.

While university novels told from the perspective of faculty are more likely to use classroom scenes to illustrate the character of the teacher, novels focused on students are more likely to use them to illuminate the characters of students. The first scenes of teaching in Tom Wolfe's I am Charlotte Simmons (2004), in which an innocent, highachieving country girl tries to make sense of life on an elite university campus and eventually gives up her search for the life of the mind in favor of the socially prestigious role of a basketball star's girlfriend, serve to demonstrate her greater dedication to learning in comparison to her classmates - who have, at least some of them, read Madame Bovary in English rather than French and who fail to answer all but the most basic questions about the novel well - as well as to show how basketball player 
Jojo Johanssen gives in to peer pressure to act as though he has not studied (99-102). It also sets in motion the relationship between the two, as they run into each other afterwards and, when he asks her to lunch, she confronts him about his choice to "say something foolish" when he knew the answer to one of the professor's questions (106). Later scenes set in a neuroscience course show Charlotte's decreasing level of preparation as she moves from being able to answer any and all questions, to feeling guilty over her lack of study when she is unable to do so. Depicting how Charlotte changes, however, only requires that a few brief exchanges between the professor and the students be quoted; the rest is summarized or simply passed over in favor of her internal monologue.

Campus novels that also belong to other genres have further limits on what classroom scenes they may include. Murder mysteries such as Shirley Allan's Academic Body (2010) and Lesley A. Diehl's Murder Is Academic (2014) must focus on their characters' efforts to uncover the killer and build up the sense of a threat to the still-living in order to create tension. Ruth Dudley Edwards' Murdering Americans - in which Baroness "Jack" Troutbeck, a conservative member of the House of Lords and Mistress of St. Martha's College in Cambridge, travels to the fictional Freeman College in America to take up the post of Distinguished Visiting Professor and finds herself simultaneously battling the "politically correct" campus culture and investigating the death of the previous Provost - departs from this rule somewhat due to its satirical exploration of campus politics with the main character spending perhaps too much time ranting against what she sees as the ignorance and foolishness of liberal American academics.

Romance (in the Mills \& Boon or Harlequin sense, rather than the more traditional sense in which Lodge's Small World is a romance) and erotica such as Lian Dolan's Elizabeth the First Wife (2013) and Tara Crescent's The Professor's Pet (2014) must focus on the development of relationships and sex scenes rather than classroom teaching. Though it would be possible for an author to set some of these actions in a classroom, writers in these sub-genres of the campus novel typically avoid doing so, perhaps because the seriousness of the ethical issue that would thus be raised would be inappropriate for such a light genre. Often, 
however, as is the case with Crescent's novel, there is a pedagogical element; in the case of The Professor's Pet, a more experienced man (and a professor) teaches a younger woman (a graduate student who has just defended her dissertation). It is perhaps a shame that these novels do not present enough information about the dominant partner's classroom teaching to allow for a comparison. Then again, it might be argued that such works are not truly university fiction but, rather, works (belonging to romance genres which have highly restrictive conventions) that simply happen to be set on university campuses. These novels lack, for example, the kind of self-conscious bad choices and the critique of excessively intellectualized or carnal sexuality that Jesse Kavadlo describes as characterizing the campus novel at the end of the twentieth century, or even the sort of reference to them that would suggest generic development rather than generic difference.

Nonetheless, despite the minimization of classroom scenes, teaching clearly matters to sympathetic professorial characters in campus novels, even if they must struggle to teach; corrupt characters, on the other hand, consider learning and teaching secondary at best. Though critics such as William G. Tierney have observed that in the contemporary tenure-centered academic novel, teaching is irrelevant (172), what they leave out is that the novels in fact generally critique the position that teaching does not matter. In the moral economy of the campus novel, pedagogy does matter, regardless of whether or not it does to students, administrators, and legislators. If learning and teaching have been socially devalued, that cannot fully explain the lack of classroom scenes in the campus novel because these works and their authors, for the most part, oppose such devaluation.

That they care about pedagogy is the most reliably present trait found among sympathetic characters in university novels. In Academic Body, though the classroom scenes are passed over in summary, Shirley Allen's retired theatrical director and protagonist, Paul, new to the academic profession, makes constant efforts to improve as a pedagogue under the tutelage of the more experienced instructor Emily, turning to her for advice whenever essays or other student work fails to meet his standards. Rather than blaming the students entirely for such failures, he 
sees them as a sign that he must improve as an instructor. A more detailed example is the academic protagonist of Lodge's Nice Work, the third novel in his trilogy. Teaching is often one of the first things Robyn Penrose thinks about:

she gives priority to the fact that it is the first day of the winter term, and that she has a lecture to deliver and two tutorials to conduct. Although she has been teaching now for some eight years, on and off, although she enjoys it, feels she is good at it, and would like to go on doing it for the rest of her life if possible, she always feels a twinge of anxiety at the beginning of a new term. This does not disturb her self-confidence: a good teacher, like a good actress, should not be immune from stage fright. (Lodge 556)

The nervousness signals both that teaching is a kind of performance and that this performance is important to Penrose. Later, she struggles with why what she teaches should matter, noting that when Wilcox tells her that arts degrees aren't worth the money spent on them, her only comeback is to rely

on arguments that I don't really believe any more, like the importance of maintaining cultural tradition, and improving students' communicative skills - arguments old fogeys like Philip Swallow trot out at the drop of a hat. Because if I said we teach students about the perpetual sliding of the signified under the signifier, or the way every text inevitably undermines its own claims to a determinate meaning, he would laugh in my face. (Lodge 685)

While she never quite resolves this issue, she does continue to question it and, in her imagining of a university where students and workers can meet together, which plays into her decision to remain at Rummidge instead of taking a position in the U.S. (Lodge 811), shows that this consideration has led her at least to conceive of a possible route to an answer.

In contrast with characters such as Robyn Penrose, corrupt faculty members typically fail to care about learning and teaching. In Jane Smiley's Moo (1995), for instance, the same economics professor who attempts to help a corporation mine a gold vein running under a Costa Rican cloud forest, though a popular and entertaining lecturer, leaves his final examinations to be proctored by his teaching assistants and graded 
by computer (245). He is willing to sacrifice a valuable ecosystem for corporate profits - and his own fees, of course - just as he is willing to sacrifice the potential of summative evaluations as a learning tool which, as Ken Bain has argued, the "best" university teachers take full advantage of (151-2) - in order to maximize his time for pursuing other ends. The situations may not be precisely the same, but they do illustrate how characters in university fiction who neglect their teaching typically also neglect other obligations, whether social, civic, or simply job-related.

Occasionally, characters who start out sympathetic lose this quality and their attitude towards teaching changes accordingly. When Nelson Humboldt, the central character of James Hynes' The Lecturer's Tale (2001), becomes fully corrupted by the power of his reattached finger to force his will upon others - using it to advance his career instead of his officemate's - he puts the chair of the department into a coma, nearly murders an aggressive panhandler, and hands all his courses over to a graduate student. Even then, he cares enough about how and what is taught, requiring his TA to follow his syllabus precisely (Hynes 325). Before, as a powerless visiting adjunct lecturer, Humboldt was so conscientious about his teaching that one of his immediate concerns when he loses his position for the following term was how to compose himself for the class he had to teach ten minutes later (Hynes 4).

Other characters in this satiric work are corrupt from the start, and their pedagogy or lack of dedication to it, demonstrates this corruption. Walter Midlist - an aptonym that illustrates the source of the bitterness that permeates his teaching - crushed the undergraduate Humboldt's hope of becoming a novelist, as he has crushed the hopes of many young men who then gather at his house for drugs and a travesty of mentorship:

Sprawled at the feet of their master, their eyes dilated as wide as olive pits, these acolytes in the cult of failure ripped on the reputation of every published writer since Jonathan Swift. Unlike the rest of them, Nelson had read most of the work they were demolishing, but his talent for quotation impressed them only if he did it with a sneer. (Hynes 17)

Mind expanding, indeed. 
By contrast, when Humboldt's finger is permanently detached and the magic is broken, he seeks redemption in a rededication to pedagogy. At first, he tries to convince a more successful faculty member to stay following the destruction of the research library, stating that they can

build a department from scratch . . . we could combine teaching and research in a whole new way, make them reinforce each other the way they're supposed to . . . and lure the best teachers and scholars here with the chance to participate in something really revolutionary, a university where pedagogy and scholarship are the same thing, where a good day in class is as exciting as another publication. (Hynes 369)

He seeks to codify the way research feeds teaching, to make the structure of tenure reflect their interrelatedness, though he seems unaware of the possibility that such reinforcement already exists in the work of academics more successful than himself, as other novels in the genre suggest.

Though the sale of the university to a corporation aborts the fulfillment of this vision, he continues to seek redemption through educational practice. The students who come to the newly privatized Midwestern are mostly minorities and/or from economically disadvantaged backgrounds. In response to the challenges of teaching them, Nelson tells himself that "This was real teaching. . . introducing literature to those who had never seen it before in their lives" (Hynes 385). While this thought may seem specious - a desperate attempt to reconcile himself to working with less-prepared students at an institution no longer dedicated to research - the possibility of doing "real teaching" providing comfort in such circumstances demonstrates the value of teaching to post-magic-finger Nelson.

Similarly, the former chair wakes from his Humboldt-induced coma and rededicates himself to pedagogy - an act of redemption for the former academic powerbroker. His new dedication to teaching puts him in direct conflict with the private company now controlling the campus: their "'recommended' syllabi for the undergraduate language arts curriculum" focus on texts from popular culture (from Carrie to Vogue to Ally McBeal), while Tony, in his return to teaching, has also returned to "the same great, canonical works of literature that had rescued him from the docklands of New Jersey" (Hynes 380). Tony observes that most of the 
remaining instructors will follow the syllabi for the cash incentives offered but wonders, "What about the kids, is what I wanna know . . . Who gives a fuck about them?" (Hynes 381). While I do not necessarily agree with him about the relative pedagogical value of canonical and popular texts, I do recognize that his new dedication to the former emerges from an ethical stance profoundly concerned with education rather than professional standing.

Indeed, such pedagogical issues are often important in the campus novel. In Changing Places, one of the major campus battles that the British academic Philip Swallow encounters during his faculty exchange year at Euphoric State (a stand-in for the University of California, Berkeley) in 1969 is over whether an assistant professor popular for his teaching methods - including letting students grade themselves - should be awarded tenure (Lodge 53). In another illustration of how issues of teaching and learning matter in scenes outside the classroom, during the job interview that opens Daniel Curzon's Among the Carnivores the panel not only emphasizes that the university emphasizes teaching over research, but also asks Jock, the candidate, whether he believes creative writing can be taught - a still-controversial question. His answer is politic: "You can't give anybody talent if he or she doesn't have it, but you can encourage it when you find it" (16-17). The Shakespearean scholar on the committee goes on to enquire about the rigor of creative writing courses, continuing the theme of questioning pedagogy. McCarthy's The Groves of Academe (1952) similarly focuses on teaching as an issue in decisions of hiring and firing. The novel is set at Jocelyn, a Small Liberal Arts College that boasts of its progressive program and individual instruction, and the issue of whether the central character is a good teacher whose contract should be renewed hinges in part on whether his failures to fulfill certain institutional demands reflect a profound, perhaps subconscious disagreement with the college's preferred pedagogical methods. The department chair tells his faculty, "I think it very probable that Hen literally cannot fill out our achievement sheet. More power to him, in a way; one can't help but respect an integrity that buckles at putting a check beside 'prejudiced but genial' or 'truly liberal'” (1516-18). To the chair, however, this integrity makes Henry Mulcahy a poor fit for the school. 
The exception to this apparent authorial valuation of teaching comes in especially cynical academic novels, such as Kingsley Amis's 1954 Lucky Jim. The closest we get to seeing the eponymous James Dixon teach is a public lecture that turns disastrous because of his excessive drinking. Earlier, in scenes that suggest his actual teaching may not be much more effective than that lecture, Dixon tries to dissuade Michie, a young man whose questions challenge Dixon's bluffing his way through teaching, from taking his special topic course, while also hoping to register the female students he considers most attractive. Then again, he takes a similar approach to research, attempting to avoid any more effort than is needed to keep his post. As it happens, he is removed from his position at the end of his first academic year - though none of the characters who remain in their posts seems more sympathetic. In novels such as Amis's, the devaluation of teaching is part of a general devaluation of the university itself; teaching may not be important, but then neither is the research conducted by the academics of particular interest either. In such a context, a lack of classroom scenes relative to depictions of other aspects of university life cannot be explained simply by the lack of importance placed on pedagogy because no aspect of university life is important.

In other novels, when teaching and learning do matter, concern with such issues often manifests in pedagogy that happens outside the classroom. Grading and commenting on essays are perhaps the most common alternative sites of teaching, though like classroom scenes, these acts are commonly summarized due to their lack of dramatic potential. Allen's Paul, taking the advice of Emily after receiving a disappointing batch of student papers, sets about "assigning grades and writing comments on the student papers that he hoped would improve their next efforts" (1349-50). Grading, ideally, is not merely an act of evaluation but also one of instruction and guidance. Jane Smiley's Moo, a humorous novel about the struggles of an ensemble of students, staff, and faculty at a Midwestern university of no great distinction, arguably does the most with written-feedback-as-pedagogy, presenting in four instances a creative writing assignment followed by a version of a story based on a young man's imagining the future of his roommate and his roommate's 
girlfriend; interleaved with these assignments are notes from the instructor, Timothy Monahan, critiquing the work or suggesting new directions. Initially, as Monahan points out, the young writer, Gary, is "preoccupied with Lydia's [imagined future] fatness. Does fatness itself make her unlikable? That's what you seem to be implying" (83-84). For later assignments, based in revision, Monahan insists that the student "find some redeeming qualities of character OR personality in the Lydia figure" (125). On the first attempt, the student rewrites the story so that she regrets her changes from a lithe college student to a fat older woman and inadequate mother, but he eventually moves through multiple perspectives to notice how she has been mistreated, in reality, by her current real boyfriend. After the couple breaks up, Gary asks her out and has a conversation with her about her life and background that eventually leads him to write a layered version of the story in which fat Lydia represents a nightmare her current self is having and another version of herself observes her having. Monahan's suggestions help the young man not only to write more three-dimensional characters but also to begin to see the people he has based them on more fully. He matures as a person and a writer because of this outside-the-classroom teaching.

Another form of professorial writing, reference letters, represents part of the educator's mentoring role. Dear Committee Members is an epistolary novel entirely built around a responsibility that faculty members have for students beyond the classroom: writing letters of recommendation often, though not exclusively, for students and former students. While some of these references are perfunctory notes for wage work, others manifest a deep concern for students, as when the writer tries to find a situation for a student who has lost his funding that will allow him to continue work on his novel - acting, in other words, as a concerned mentor. Similarly, in Changing Places, Philip Swallow has written numerous letters on behalf of the iconoclastic Charles Boon, including as part of a successful application for a graduate fellowship at the American university Euphoric State (Lodge 28-29), where Swallow (on faculty exchange) and Boon develop a surprising friendship.

Swallow also uses his friendship with Boon to take on the role of a public intellectual, going on his radio show and 
dispensing liberal wisdom ... on every conceivable subject - the Garden, drugs, law and order, academic standards, Viet Nam, the environment, nuclear testing, abortion, encounter groups, the Underground press, the death of the novel, and even now he had enough energy and enthusiasm left to find a word on the Sexual Revolution for the old lady. (Lodge 161).

He takes the act of lecturing from the classroom to the airwaves and so broadens both the site of teaching and the number of students he can reach - or at least, he believes that is what he is doing, right up until his wife back in Britain calls in, leading to an on-air drama Boon relishes. Despite its ignoble conclusion, the scene demonstrates at least the potential and desire to teach outside the lecture hall.

Where Swallow brings the act of pedagogy outside the institution, in other cases, external forces and visitors influence pedagogy within the institution. McCarthy's The Groves of Academe concludes with a poetry conference for which different factions on campus had different pedagogical hopes. When the conference committee - Henry Mulcahy and his protégé, the poet Ellie Ellison - are called to account for reports from students that they have been setting the conference up to allow for an attack on elder poets by younger ones, the latter responds that they have simply been trying to generate interest through controversy, to teach students "to take poetry seriously, like a baseball game . . . Choosing up sides. It's the only way to run these things, to give them the quality of a mythic contest" (2833-35). Whatever the validity of such an approach (and the rest of Jocelyn's faculty remains unconvinced), this defense calls on a common understanding of a hosted conference as an opportunity for student learning.

What all these instances of pedagogy beyond the classroom illustrate is that to assume that teaching is unimportant simply because the classroom is not dwelled upon would be a mistake. It is, after all, those learning experiences that go beyond the walls of formal settings that have the greatest potential to meet the needs of traditional narrative and of memory-as-narrative. As Donald Finkel points out, students tend to remember best the learning that occurs outside the classroom, and "if a teacher or teacher-like figure was important to your learning, she was probably doing something different from enthusiastic Telling" (7). Given 
that neither the best learning nor the more interesting stories take place in the classroom, the relative lack of prominence of the classroom cannot be considered an essential criterion for measuring the importance of pedagogy to the genre of university fiction, or to the university itself.

Indeed, if instruction is unimportant in the campus novel, that unimportance is primarily expressed through the demands of administration. Faculty struggle with administration in order to teach, and these struggles become part of the narrative of education. Especially over the last twenty-five years, these novels have dramatized how administrative overreach increasingly takes up the time of or otherwise impedes academic faculty, whether through the addition of more duties administrative in nature - meetings, paperwork - or through work even more removed from teaching and learning, created by administrations. The struggle to teach, or to learn, is not a collective struggle shared by administrators, teachers, and students but, rather, a struggle against administration.

Struggles against administration reach their cruelest expression in campus novels that are also mysteries; as Ms. Mentor points out in her 2015 "Annual Guide to Academic Novels," deans make the most popular victims in such novels. In Allen's Academic Body, the would-be-professor protagonist's actress wife, prior to the murder, compares the dean unfavorably to the "tyrants" of the theatrical world (42-44). Diehl's Murder Is Academic, on the other hand, deviates from this pattern to kill a higher-ranking administrator: the campus president.

In other cases, the struggle is less violent and, often, more explicitly tied to the struggle to teach. The plot of the final novel of David Lodge's Campus Trilogy, Nice Work, first published in 1989, revolves around this latter sort of struggle. It falls to Robyn Penrose, a young academic on a temporary contract, to shadow a factory managing director, fulfilling a program contrived by the Vice Chancellor. The one day a week she spends in the factory is normally the one "she spent at home, catching up on her marking, preparation, and research" (593). Two thirds of the duties this administrative scheme has reduced her time to fulfill in are related to teaching, but she quasi-volunteers for the post in order to increase the chance that she will be able to continue teaching when her temporary 
contract expires. When Mary McCarthy's protagonist, Henry Mulcahy, receives the letter from the college president that will catalyze the novel's plot, his response reflects that he is engaged, similarly, in a struggle to teach: he emits "a sudden sharp cry of impatience and irritation, as if such interruptions could positively be brooked no longer . . . How was he expected to take care of forty students if other demands on his attention were continually being put in the way?" (18-20). What he does not know, even as he responds with irritation, is that the missive states that his contract for the following year will not be renewed. Even if the administrative demand had been reasonable or well-intentioned, it would still have taken time away from teaching. While such demands may be in part responsible for the diminished importance of classroom scenes in the campus novel, they also contribute to the idea that a narrative of education is a narrative of struggle.

In contemporary campus novels, the struggle with administration often becomes even more central to the plot and more Manichean, with protagonists struggling against sinister machinations not only of the administration on campus but also with trustees and members of state government. Lawrence S. Wittner's What's Going On at UAardvark? (2013) and Joel Shatzky's Option Three (2012) respectively provide optimistic and pessimistic examples - both satirical. What's Going On at UAardvark?, framed by extraterrestrial memoranda about the educational value of the story for anyone interested in Earth society, describes a campus revolt against extreme corporatization; faculty, students, and staff (especially the campus cleaners) struggle together to take over the university and establish a new cooperative regime for learning, teaching, and working. By contrast, in Option Three, the profit motive leads to the sale of university departments to corporations, the revocation of tenure and adjunctification of the entire faculty, and eventually the replacement of professors with hologram versions of themselves. In this less utopian vision, students strive both for and against these changes. In both novels, the radical changes wrought by administrations and the struggles that respond to them become key elements of the students' experiences of a university education: the struggle itself becomes a site of learning. 
Option Three, however, has a twist. Though profit motivates many of the administrators, the masterminds on the Board of Trustees have another aim: one elitist yet pedagogical. They believe that the majority of university students do not belong there and wish to drive off all but the most motivated and highest achieving among them. This move represents a logical, though extreme, end of grousing about underprepared students, which is not uncommon among faculty either in novels or in real life. In the end, as students who remain - students from both sides of the struggle - follow one of the few living faculty still teaching into a lecture hall, readers are left to imagine the future and so to make a value judgment. With both those faculty whose reliance on lecture allowed them to be replaced with holographic recording and those students who were not intrinsically motivated to learn gone, will the pedagogical environment improve? And if so, is it worth the denial of an education to less motivated students?

In all these cases, the struggles of faculty and students against administrators become part of these narratives of teaching and learning. In What's Going On at UAardvark? students have learned to organize and define their own education. In Option Three, those students who once supported the introduction of advertisements into lectures and the replacement of lecturers with holograms have begun to see the problems such measures lead to. At least, the students see these issues well enough to want to be taught by the live faculty member whom they once opposed. Administrators, however, are not the only antagonists that learners and teachers face in university fiction. Just as faculty struggle against administrative demands so that they may teach, so do faculty and students alike struggle with the physical locations of their work. At UAardvark, the main character Jake empathizes with his students who miss class because, due to leaks, a lack of windows, and the regular disappearance of essential furniture, "the classroom certainly did not provide a learning-friendly environment" (Wittner 208-12). The dogged letter-writer of Julie Schumacher's Dear Committee Members (2014) weaves complaints about the conditions of the building he works from into his missives. Given that the poor state of the buildings often results from budgetary decisions, 
these struggles with the physical locations of learning and teaching can be seen as part of the struggle with administration.

On the other hand, those novels that focus on students rather than faculty in particular suggest that the sort of subjects taught in the classroom are not always the most valued kinds of learning. The eponymous Charlotte Simmons's change from an innocent, studious girl from a small town to a basketball player's girlfriend more interested in popularity than intellect may be read as a corruption or loss of self so that her reduction of interest in learning parallels the corruption and loss of interest in teaching experienced by faculty characters in other campus novels. On the other hand, it can be seen as an alternative kind of education, as she learns the rules of her new social milieu and how to gain the admiration of her peers that she has sought from the beginning. Her internal monologue while watching the game that concludes the novel bears out this conundrum: "Wasn't it Charlotte Simmons who wanted a life of the mind? Or was what she wanted all along to be considered special and to be admired for that in itself, no matter how she achieved it?" (Wolfe 675).

While such examples suggest a common cynicism about the motives of college students, they also support the idea of education, in memory, as a narrative of struggle, as certainly that is how these main characters would remember their university years. Given the limits of the classroom scene in fulfilling the demands of the novel form, the prevalence of student-protagonists whose focus is outside their formal studies reflects the limits of the genre. The narrative needs of the novel and of memory converge.

The requirements of the traditional novel shape how the campus novel depicts learning and teaching in ways similar to the process of creating a remembered narrative of one's own education. Formal sites of learning, such as the classroom, become secondary to informal contacts, conversation, and experience. Formal lessons and lectures establish or support the ideas about education - the themes and character development - that express themselves primarily outside the classroom. It is tempting to reduce this relationship to that of theory and praxis - or to the division between theory and reality that Eagleton traces in Lodge's Nice Work (97- 
102) - but that would be an oversimplification. When we make stories about education, whether in our memories or in the traditional narrative form preferred by writers of university novels, the classroom is not a space apart but, rather, merely one space in which the process of socialization we call education takes place; actions in the classroom are affected by dynamics outside of them, and the relationships built within the classroom walls persist beyond them, at least in the imagination, and our pedagogies should take account of the porousness of all campus walls.

\section{Works Cited}

Allen, Shirley. Academic Body. Wetherfield, CT: Mainly Murder Press, 2010. Kindle.

Amis, Kingsley. Lucky Jim. New York: NYRB Classics, 2012. Kindle.

Bain, Ken. What the Best College Teachers Do. Cambridge: Harvard UP, 2011. Kindle.

Bradbury, Malcolm. Eating People Is Wrong. New York: Pan Macmillan, 2012. Kindle.

Crescent, Tara. The Professor's Pet. Seattle: Amazon Digital Services, 2014. Kindle.

Curzon, Daniel. Among the Carnivores. San Francisco: IGNA Books, 2005. Print.

Diehl, Lesley A. Murder Is Academic. Lesley A. Diehl, 2014. Kindle.

Dolan, Lian. Elizabeth the First Wife. Brooklyn: Prospect Park Books, 2013. Print.

Eagleton, Terry. "The Silences of David Lodge." New Left Review I.172 (1988): 93-102. Web. 26 July 2015.

Edwards, Ruth Dudley. Murdering Americans: A Robert Amiss/Baroness Jack Troutbeck Mystery. Scottsdale, AZ: Poisoned Pen Press Inc, 2011. Print.

Fiedler, Leslie. "The War Against the Academy." The Academic Novel: New and Classic Essays. Ed. Merritt Moseley. Chester: Chester Academic Press, 2007. 44-62. Print.

Finkel, Donald. Teaching with Your Mouth Shut. Portsmouth, NH: Heinemann, 2000. Print

Hynes, James. The Lecturer's Tale. New York: Picador, 2001. Print.

Joyce, James. A Portrait of the Artist as a Young Man. Ed. Chester G. Anderson and Richard Ellmann. New York: Viking Press, 1964. Print.

---. Ulysses. Ed. Hans Walter Gabler, et al. New York: Garland Publishing, 1986. Print.

Kavadlo, Jesse. "Blue Angels Meet Dying Animals: Textual and Sexual Subversion in the Clinton-Era Academic Novel." The Journal of the Midwest Modern Language Association 37.2 (2004): 11-25. JSTOR. Web. 18 Aug. 2015. 
Lodge, David. The Campus Trilogy. New York: Penguin Books, 2011. Print.

McCarthy, Mary. The Groves of Academe: A Novel. New York: Open Road Media, 2013. Kindle.

Mentor, Ms. "Ms. Mentor's Annual Guide to Academic Novels." The Chronicle of Higher Education 6 Aug. 2015. Web. 16 July 2015.

Rossen, Janice. The University in Modern Fiction: When Power Is Academic. New York: St. Martin's Press, 1993. Print.

Schumacher, Julie. Dear Committee Members. New York: Doubleday, 2014. Print.

Shatzky, Joel. Option Three: A Novel about the University. Accord, NY: Jewish Currents, 2012. Kindle.

Smiley, Jane. Moo. New York: Anchor, 2011. Kindle.

Tierney, William G. "Academic Freedom and Tenure: Between Fiction and Reality." The Journal of Higher Education 75.2 (2004): 161-177. Project MUSE. Web. 6 Aug. 2015.

Van Lier, Leo. The Ecology and Semiotics of Language Learning: A Sociocultural Perspective. Boston: Kluwer Academic, 2004. Print.

Weesner, Theodore. Novemberfest. Hanover: University Press of New England, 1994. Print.

Wilson, Keith. "Academic Fictions and the Place of Liberal Studies: A Leavis Inheritance." University Fiction. Ed. David Bevan. Amsterdam: Rodopi, 1990. 5774. Print.

Wittner, Lawrence S. What's Going On at UAardvark? Solidarity Press, 2013. Kindle.

Wolfe, Tom. I Am Charlotte Simmons: A Novel. New York: Farrar, Straus and Giroux, 2004. Kindle. 